\title{
As denúncias de torturas e torturadores a partir dos cárceres políticos brasileiros
}

Janaína de Almeida Telles*

\section{Resumo}

0 período ditatorial brasileiro foi marcado por notórios abusos aos direitos humanos, perpetrados pelas forças repressivas, dentro de uma intrincada estrutura de poder que uniu órgãos dedicados à vigilância social, unidades militares, polícia civil e política. Neste contexto, a sistematização e divulgação das denúncias acerca dos abusos estatais teve papel determinante no desgaste do regime. Este estudo apresenta o resultado de uma pesquisa de campo em que foram realizadas 107 entrevistas com ex-presos políticos, advogados e militantes de direitos humanos que tiveram atuação relevante no período, com o objetivo de auxiliar a compreensão dos caminhos seguidos para sensibilizar a opinião pública nacional e internacional acerca da extensão da violência estatal que se praticava no Brasil. Estas entrevistas levaram à produção de balanços críticos originais sobre a atuação dos presos políticos e seu legado, os quais são apresentados à luz de referências teóricas pertinentes.

\section{Palavras-chave}

Ditadura Militar. Tortura. Presos Políticos.

\begin{abstract}
The Brazilian dictatorial period was marked by notorious human rights abuses perpetrated by the repressive forces inside an intrincate power strutucture that united organisms dedicated to social vigilance, military unities, civil and political police. In this context, the systematization and publicization of the indictments on the state abuses had a determinant role in the erosion of the regime. This study presents the result of a fieldwork that conducted 107 interviews with former political prisoners, lawyers and human rights militants of relevance to the period aiming to help the understanding of the strategies adopted to sensibilise the national and international public opinion on the extent of the state violence practiced in Brazil. These
\end{abstract}

\footnotetext{
* Pesquisadora do Programa de Pós-Doutorado em História Social da Universidade de São Paulo. Mestre e Doutora em História Social pela mesma instituição. Coorganizadora de Desarquivando a Ditadura. Memória e Justiça no Brasil. São Paulo, Hucitec, 2009, v. 1 e 2, entre outros.
} 
interviews led to the production of original critical reports about the work of political prisoners and their legacy in light of pertinent theoretical references.

\section{Keywords}

Military dictatorship. Torture. Political prisoners.

\section{Introdução - o resgate das denúncias pela via da memória autobiográfica}

No Brasil, o processo de reconstituição factual e de reflexão crítica acerca da ditadura militar permanece incompleto e permeado por zonas de silêncio e interdições. Decorridos pouco mais de 29 anos desde o fim do regime de exceção, muitos acontecimentos permanecem desconhecidos. Ao mesmo tempo, se observa a existência de importantes lacunas nas articulações entre o passado e o presente no que tange ao legado da ditadura e à memória daqueles que a ela se opuseram ativamente.

Visando contribuir para o entendimento deste processo histórico e de seu legado, este texto procura caracterizar o protagonismo dos presos políticos nas lutas de resistência à ditadura no Brasil durante os anos 1970 por meio de sua atuação na sistematização e divulgação de denúncias de violações dos direitos humanos; em especial, das listas de torturadores. Ao mesmo tempo, pretende-se oferecer elementos para a elaboração de um panorama reflexivo sobre a construção de suas memórias a respeito dessas lutas.

Para alcançar esses objetivos, este estudo pauta-se pelo registro das memórias dos presos políticos - um conjunto de 107 entrevistas realizadas com ex-presos políticos, advogados e militantes dos direitos humanos, constituído ao longo de minha pesquisa de doutorado (TELES, 2011). Tal registro permitiu traçar um quadro a respeito da organização dos presos e sua rede de solidariedade, assim como aprofundar o conhecimento sobre as disputas políticas estabelecidas dentro e fora dos cárceres.

Os testemunhos compilados e os documentos consultados revelaram a efetiva importância dos presos políticos na sistematização e divulgação das denúncias dos crimes da ditadura, contribuindo decisivamente para seu desgaste. Sobreviventes, familiares e militantes constituíram redes de solidariedade aos presos e perseguidos políticos durante os anos de 1970 que 
foram cruciais para as lutas de resistência e para a democratização do país.

Sob tal perspectiva, o estudo caracteriza-se, em sua especificidade, pela abordagem escolhida para a produção do panorama das denúncias dos presos encarcerados e pela tônica concedida às redes de relações nas quais esses sujeitos históricos estavam inseridos, abrindo uma janela de oportunidades para uma visão singular dos dados compilados e dos acontecimentos.

\section{Das torturas às denúncias}

O contexto repressivo sob o qual vicejaram os diversos abusos perpetrados pela ditadura brasileira caracterizou-se por uma intrincada estrutura, que ganhou contornos específicos a partir de 1967, com a formação dos "organismos mistos" nas forças armadas, os quais combinavam operações de informação e de repressão (FICO, 2001, p.91-92). Especialmente, a partir da edição do AI-5, de dezembro de 1968, intensificou-se a formação de uma rede de unidades secretas e clandestinas que gerou o sistema DOI-Codi (Destacamentos de Operações de Informações - Centros de Operações de Defesa Interna), o qual era controlado pelo Exército e resguardava certa autonomia operacional (FICO, 2004, p. 83).

A articulação de diversas modalidades repressivas, aliando desde os centros clandestinos de extermínio até a justiça militar e o sistema carcerário, exigiu a estruturação de um aparelho burocrático sofisticado do Estado, que contou com altos níveis de colaboração entre civis e militares. Nesse contexto, o poder executivo foi agudamente ampliado. Esta estruturação possibilitou a divisão de responsabilidades e certa margem para administrar o poder e as disputas dentro e fora do aparelho de Estado. Produziu-se, desse modo, uma legalidade de exceção e uma grande estrutura administrativa e institucional que possuía relativa eficiência; uma estrutura de poder que passou a dar um "significado jurídico a uma esfera de ação em si extrajurídica" (AGAMBEN, 2004b, p. 24), própria do estado de exceção, no qual a suspensão da ordem jurídica é sua condição extrema.

Essa legalidade de exceção possibilitou a coexistência de órgãos e instituições como os campos de concentração na Guerrilha do Araguaia, os DOI-Codi, a rede de centros clandestinos de extermínio, os DOPS, a justiça militar e os presídios; uma das chaves determinantes do êxito da ditadura por um período relativamente longo. Esta sobreposição de hierarquias era parte da lógica repressiva, que criou uma gama diversificada de órgãos e 
funções que, a despeito de sua extensão, centralizava a decisão sobre a vida e a morte dos perseguidos políticos e dos considerados "irrecuperáveis" (TELES, 2011).

Tal contexto representa mais que o simples pano de fundo às denúncias, ele fornece um guia para a compreensão das estratégias assumidas pelos diversos grupos de resistência e, frequentemente, para um balanço dos resultados atingidos. Desde o início da ditadura, ocorreram diversas manifestações visando expor as práticas violentas do regime. Denúncias e listas de vítimas de tortura, assassinatos e desaparecimentos forçados, assim como listas de torturadores foram sistematizadas por diversos grupos e partidos políticos, as quais chegaram à Comissão Internacional de Juristas (CIJ), à Organização dos Estados Americanos (OEA) e à Anistia Internacional (AI), entre outros organismos internacionais de defesa dos direitos humanos.

Alguns assassinatos geraram grande impacto na opinião pública nacional e internacional, especialmente após a edição do AI-5 ${ }^{1}$. Desde a divulgação do assassinato do assessor do arcebispo D. Helder Câmara, o padre católico Antônio Henrique Pereira Neto, na cidade de Recife em maio de $1969^{2}$, e das denúncias de violações aos direitos humanos feitas pelos prisioneiros políticos libertados em troca do embaixador dos Estados Unidos, em setembro de 1969 na Cidade do México (DA-RIN, 2008), várias manifestações de protesto se espalharam no exterior. Uma rede mundial de ativistas, católicos e exilados se mobilizou em apoio às vítimas da ditadura, dando visibilidade ao que acontecia no Brasil.

O assassinato sob tortura do militante da "Var-Palmares", Chael Charles Schreier, em novembro de 1969, teve grande repercussão; especialmente após a publicação da matéria de capa da revista Veja, intitulada "Tortura". A notícia de sua morte e das torturas sofridas por Maria Auxiliadora Lara Barcellos e seu companheiro Antonio Roberto Espinosa na Vila Militar do Rio de Janeiro foi assunto nos principais jornais dos Estados Unidos, da França e da Inglaterra (ESPINOSA, 2009). Naquele mês dar-se-ia também a criação da

\footnotetext{
${ }^{1}$ Para referências sobre a comissão de investigação acerca das denúncias de tortura de 1964, ver: ALVES (1967); ALMEIDA (2009), p.78-80. Sobre a CPI criada para apurar a morte de Soares, ver: ALMEIDA (2009), p.101-104.

2 Para referências sobre a morte de padre Henrique, ver: ALMEIDA (2009), p.139-140; e GREEN (2009), p.162-6.

${ }^{3}$ Cf. a revista Veja, "Tortura”, 03/12/69 e ALMEIDA (2009), p.164-166.
} 
Frente Brasileira de Informações (FBI) no Chile e na Argélia. Articulada em torno de Miguel Arraes, tratava-se de uma frente de esquerdas criada para divulgar no exílio os crimes da ditadura. Pouco dias depois, o FBI divulgou seu primeiro comunicado listando 36 torturadores. Outros núcleos surgiram em diversos países, tais como: Chile, Suíça e Itália, entre outros (GASPARI, 2002, p.272-73). Nesse período, um grupo formado por brasilianistas e militantes organizou-se em torno do Brazilian Information Bulletin nos Estados Unidos, o qual repercutia de maneira eficiente as notícias de violações de direitos humanos vindas do Brasil (GREEN, 2009) ${ }^{4}$.

A morte do líder sindical Olavo Hansen, militante do Partido Operário Revolucionário (PORT) assassinado em maio de 1970 no DOPS paulista, também gerou rumorosos protestos de sindicalistas e diversos pronunciamentos no Congresso Nacional. Pouco antes, no dia 2 de maio, os bispos brasileiros haviam se reunido em Brasília e emitido um documento pedindo a investigação de reiterados casos de tortura no país (IDEM, p.280). O acúmulo de denúncias levou a CIJ a divulgar em Genebra, na Suíça, um relatório sobre o Brasil em julho daquele ano, no qual afirmou que a tortura havia se tornado uma arma política e era sistematicamente aplicada. A Comissão era uma organização não governamental e tinha status consultivo perante o Conselho Econômico e Social das Nações Unidas. Seu posicionamento público e o encaminhamento dessas denúncias à OEA alcançaram grande repercussão. Seu relatório baseou-se nas denúncias feitas pelos presos políticos trocados pelo embaixador da República Federal Alemã, em junho de $1970^{5}$.

Não demorou para a Conferência Nacional dos Bispos do Brasil (CNBB) e a Igreja Católica condenarem o uso da tortura no Brasil. Em outubro, o papa Paulo VI fez um pronunciamento público em Roma a respeito, pedindo uma reflexão sobre "fatos que chocam pela sua singularidade, sua gravidade e sua repetição" (GASPARI, 2002, p.308). Em seguida, nomeou arcebispo da arquidiocese de São Paulo, D. Paulo Evaristo Arns - um franciscano da ala progressista da Igreja Católica -, cuja atuação foi crucial para a sistematização

\footnotetext{
${ }^{4}$ No início de 1970, as denúncias de tortura feitas pelos prisioneiros de Linhares (Juiz de Fora / MG) foram amplamente difundidas no exterior. A descrição de presos submetidos à tortura numa aula para oficiais inspirou uma cena do filme Estado de Sítio (1973) de Costa Gravas. Cf. PAIVA (2004), p.68-70, 120-121.

${ }^{5}$ Cf. GASPARI (2002, p.297); GREEN (2009, p.287).
} 
e divulgação das violações de direitos humanos no país (BENEVIDES, 2009). No final de 1970, os principais jornais europeus e norte-americanos já haviam publicado numerosos artigos que apresentavam uma imagem bastante negativa da ditadura brasileira (GREEN, 2009, p.297).

A chegada dos presos políticos trocados pelo embaixador suíço ao Chile em 1971 gerou nova onda de denúncias sobre a violência estatal brasileira no exterior ${ }^{6}$. Outros casos de tortura, assassinatos e desaparecimentos forçados chegaram ao conhecimento de setores mais amplos da sociedade no país; mas, o governo opôs forte resistência a qualquer investigação de responsabilidades (TELES, 2005).

Em julho de 1972, chegou ao Brasil em missão de inquérito o representante do Secretariado Internacional de Juristas Católicos e da Associação Internacional de Juristas Democráticos, solicitada em face da greve de fome de presos políticos de São Paulo, que se prolongava havia muitos dias. Ele não obteve autorização para entrar em nenhum presídio. Seu parecer sobre a situação foi incluído como um adendo ao famoso "Relatório sobre as acusações de torturas no Brasil”, da Anistia Internacional (AI), de setembro de 1972. O adendo repercutiu informações dos presos políticos, tendo destacado o término da greve de fome, 33 dias após o seu início, sem o atendimento de qualquer reivindicação (AI, 1972, p.107-8). Depois de tentar várias vezes obter autorização do governo brasileiro para conferir in loco as denúncias recebidas, a AI publicou seu relatório. $\mathrm{O}$ extenso documento de 104 páginas relaciona 1.081 vítimas de tortura, relatando as circunstâncias de tortura de alguns casos. Informa também que as investigações haviam levantado 472 nomes de torturadores, cuja lista não seria divulgada até que o governo brasileiro apreciasse o relatório. Em resposta, os militares proibiram qualquer divulgação a respeito do documento (BIOCCA, 1974, p.9).

No ano de 1974, os presos políticos estavam mais articulados, contribuindo para a sistematização das denúncias. $\mathrm{O}$ ano iniciou-se com a posse do novo presidente, o general Ernesto Geisel. A estratégia de seu governo envolveu simultaneamente o recrudescimento da repressão à Guerrilha do Araguaia

\footnotetext{
${ }^{6}$ Cf. Brazil, a report on torture (1971), Chile, 59 min. Em janeiro de 1971, os norte-americanos Saul Landau e Haskell Wexler foram ao Chile para filmar um documentário sobre Allende, mas acabaram fazendo outro, sobre os 70 prisioneiros trocados pelo embaixador da Suíça. O filme foi exibido em Washington e, pouco tempo, depois foi veiculado pela TV pública de Nova York. Cf. GREEN (2009, p. 352-355).
} 
e aos remanescentes da luta armada urbana, assim como aos membros e dirigentes do PCB, da AP-ML e de militantes católicos. Para o regime era necessário eliminar toda e qualquer forma de oposição, intimidar os setores que apoiavam e atuavam com D. Paulo E. Arns e a base social das esquerdas e da ala progressista da Igreja Católica (TELES, 2011, p.385-6).

Respondendo às diversas prisões que ocorreram nesta fase, bem como ao assassinato do estudante Alexandre Vannucchi Leme no ano anterior, foi criado em abril de 1974 o Comitê de Defesa dos Presos Políticos numa assembleia realizada no anfiteatro do prédio do curso de Ciências Sociais da Universidade de São Paulo. O DEOPS/SP iniciou um IPM para investigar a atuação dos estudantes e alguns dos presentes à reunião foram ouvidos pela delegacia de Ordem Política. Este evento motivou o DEOPS/SP a investigar a atuação dos estudantes e demais participantes, comprimindo a atuação do mesmo ${ }^{7}$.

Nesse período, denúncias sobre torturas, assassinatos e desaparecimentos forçados ocorridos no Brasil, oriundas de diversas iniciativas, foram divulgadas no Tribunal Russell II, organizado pela Fundação Lélio e Lisli Basso. Entre os dias 30 de março e 5 de abril de 1974 ocorreu a primeira sessão do Tribunal, em Roma. Composto por juristas, professores, escritores e personalidades de renome como Júlio Cortázar, o Tribunal era independente de governos e buscava legitimidade na autoridade moral e consciência da opinião pública mundial (TELES, 2005).

Conscientes da importância da divulgação dessas denúncias, o pequeno coletivo de presos políticos de São Paulo que defendeu a greve de fome de 1972 elaborou um documento em fevereiro 1974 para ser enviado ao Tribunal. Dessa vez, o relatório foi preparado com informações mais detalhadas, baseando-se em outro feito em 1973. O texto foi assinado pelo Comitê de Solidariedade aos Revolucionários do Brasil, uma organização inventada pelos presos exclusivamente para este fim $^{8}$. De acordo com o texto,

“[...] O ato de dedicarmos nosso trabalho ao Tribunal Russell representa nosso testemunho de reconhecimento pela atividade sem descanso que o mesmo vem desenvolvendo e [...] nossa

\footnotetext{
${ }^{7}$ Cf. documento do Arquivo do Estado de S. Paulo, Série Dossiês - DEOPS/SP, s/n., 14 de junho de 1974.

${ }^{8}$ Cf. CUNHA (2010); MORANO FILHO (2011).
} 
identificação com todos [...] os que resistem e lutam e morrem nos combates diários contra a opressão e a exploração.

Consagrando nosso trabalho à denúncia dos crimes da ditadura militar fascista brasileira, acreditamos estar contribuindo para o avanço da luta anti-imperialista e antifascista que se trava em escala mundial (COMITÊ, 1976, p.15-6).”

O documento foi dividido em duas partes, sendo a primeira dedicada ao "Sistema Nacional de Repressão Política"; onde ao final são descritos os instrumentos e métodos de tortura, seguidos de uma listagem de 328 nomes dos mandantes das práticas de tortura e torturadores, com os locais onde atuavam (IDEM, p.50-77). A segunda parte apresenta uma lista de 155 perseguidos políticos assassinados pela repressão, a qual foi subdividida entre: os mortos "sob tortura", com 32 casos descritos em detalhes e mais 48 nomes cujos casos não dispunham de muitas informações; e os "fuzilados ou mortos em combate", com 75 nomes, onde se incluíam alguns de desaparecidos da Guerrilha do Araguaia (IDEM, p.79-154). A conclusão do documento ressalva que esta é uma lista incompleta, pois a ditadura tudo fazia

“[...] para encobrir seus crimes: divulga informações falsas ou simplesmente não as divulga, simula tiroteios e fugas de prisioneiros, corrompe e aterroriza médicos para que forneçam laudos periciais incompletos ou falsos, desaparecem com corpos mutilados de combatentes mortos [...]. De nossa parte, arrolamos em nosso relatório os [...] casos conhecidos [...] e demos todas as indicações possíveis, de forma que todos [...] disponham de elementos mínimos que os orientem em sua incansável labuta de pesquisa e investigação e de posterior denúncia dos crimes praticados contra os povos explorados e oprimidos do mundo. Mas não temos dúvida, cedo ou tarde a verdade virá, integralmente, à tona [...] (IDEM, p.155-6).

Vários ex-presos políticos brasileiros testemunharam no Tribunal Russell. Analisando a documentação apresentada, a legislação e os testemunhos, ojúri considerou comprovado que o governo brasileiro era responsável por graves violações dos direitos humanos. O relatório do antropólogo Ettore Biocca descreveu as torturas, os locais onde ocorriam, divulgou listas de mais de mil atingidos e de torturadores, baseado no relatório da Anistia Internacional (do qual foi o redator também), entre outros. 
Esta iniciativa obteve receptividade favorável da mídia internacional, contribuindo para a formação da opinião pública a respeito da ditadura brasileira, tal como ocorreu em relação à ditadura de Pinochet no Chile, pela qual o tribunal se tornou célebre (TELES, 2011, p.389). O Tribunal contribuiu para a elaboração de novos dossiês utilizados na divulgação de denúncias e incentivou a formação de comitês e grupos de solidariedade aos perseguidos políticos do Brasil. O documento dos presos de São Paulo, por exemplo, foi publicado parcial ou integralmente nas publicações da Fundação Basso, as revistas Dossiê e Boletim, e em diversas outras pela Europ (DEL ROIO, 2011).

\section{A organização dos presos políticos à luz das greves de fome e denúncias}

As denúncias e a repercussão internacionais ocorreram em consonância com pressões importantes que os presos políticos empenharam contra o regime, as quais podem ser caracterizadas a partir das tentativas de se conquistar alas de presídios ou presídios específicos para os prisioneiros políticos. Nesse período, os prisioneiros políticos da Bahia, por exemplo, haviam conquistado uma galeria reservada apenas para eles, mas, continuavam vivendo em um ambiente de incertezas e restrições. Em abril de 1974, resolveram deflagrar uma greve de fome em protesto contra o diretor da penitenciária Lemos de Brito, que se recusou a dar atendimento médico a um dos presos. A greve durou onze dias e apenas cessou quando as reivindicações dos presos foram atendidas (JOSÉ, 2000, p.116).

Em São Paulo, na Casa de Detenção, os presos políticos conquistaram alguns direitos e condições carcerárias que lhes asseguravam certa dignidade e estabilidade, embora não fossem reconhecidos como "presos de consciência". Não obstante, em julho de 1974, a situação modificou-se substancialmente. O Secretário de Segurança Pública do Estado de São Paulo, Erasmo Dias, foi à Casa de Detenção e ficou indignado com o que presenciou. Exigiu a imediata transferência de todos os presos políticos para a Penitenciária do Estado, argumentando que: "[...] preso tinha que sentir o castigo e o peso da cadeia senão não se recuperava (SÁ, 2007, p.209).” Ele classificou e dividiu os presos políticos em dois grupos: o grupo dos considerados "recuperáveis" foi enviado para o presídio do Hipódromo, na Mooca; o outro grupo, 
composto pelos "irrecuperáveis", foi transferido para a penitenciária (IDEM, IBIDEM).

No dia 16 de julho, os presos foram levados à penitenciária (IDEM, IBIDEM); mas, já pensando em encontrar maneiras de articular sua volta e conquistar um presídio exclusivo de prisioneiros políticos. Apesar da grande dificuldade de comunicação na penitenciária, os presos políticos começaram a divulgar as denúncias de abusos aos direitos dos presos comuns visando o desgaste da direção da penitenciária. "[...] nós procuramos um entrosamento com os presos comuns, [...] e chamar advogados para defendê-los. [...] O objetivo [...] era deixar claro que incomodaríamos", conforme relatou-nos Pedro Rocha, militante do Movimento de Libertação Popular (MOLIPO), preso em São Paulo em 1971 (ROCHA, 2011). A movimentação visava obter o máximo de apoio político para, depois de esgotadas todas as possibilidades institucionais, assumir a realização de uma greve de fome. Segundo Manoel Cyrillo, militante da ALN e um dos que participaram do sequestro do embaixador norte-americano, preso em setembro de 1969:

“[...] Isso foi [...] próximo à eleição de 1974. Nós sabíamos que diversos companheiros [...] estavam apoiando candidaturas [...] da oposição. [...] A gente estava programando para o caso de vir a ser necessária uma greve de fome, que ela acontecesse durante esta campanha política, porque aí nós teríamos muito mais espaço e palanque para denunciar a nossa situação e angariar apoio à nossa luta. [...] As famílias foram à Brasília, de ônibus, para denunciar no Congresso Nacional a situação que a gente estava vivendo na Penitenciária, o absurdo que era o regime penitenciário [e tentar falar com autoridades do STM]. Enfim, esgotamos todos os caminhos legais. [...] E a greve teve muita solidariedade [...]. Buscávamos romper o cerco de silêncio [...] (CYRILLO, 2009; 2010).”

Às vésperas das eleições nacionais de 1974, no dia 24 de outubro (MORANO FILHO, 2002), os presos políticos confinados na penitenciária iniciaram a greve de fome, visando à obtenção de um presídio (exclusivo) político. Por meio de sua rede de apoio, fizeram divulgar um manifesto em que destacavam sua condição de prisioneiros políticos e a prática institucionalizada da tortura no Brasil, ambas negadas pelo Estado. O manifesto foi enviado para diversas entidades e a imprensa internacionais.

Durante à tarde, a redação da Folha de S. Paulo foi informada de que estava proibida a divulgação de toda e qualquer forma de notícia, comentários, 
editoriais sobre a greve de fome dos presos políticos de São Paulo ${ }^{9}$. De fato, nada foi publicado a respeito neste periódico. O Expresso, jornal de grande circulação em Portugal na época, entretanto, divulgou o manifesto vários dias depois, em 30 de novembro:

"Desde que se instalou no país o regime de exceção de 1964 [...] emerge para o nosso conhecimento [...] o sub-mundo do aniquilamento humano no seu mais profundo sentido. [...] a maneira como o governo tem tratado aqueles que dentro dos presídios são qualificados como Presos Políticos. [...] O que nos preocupa é a intenção dos órgãos de informação de tentar [...] demonstrar [...] que não há presos políticos no Brasil, [...] de que não existem opositores ao regime. [...] O meio mais frequentemente utilizado para a consecução de tal objetivo é a dispersão dos presos políticos em diversos presídios e estabelecimentos penais. [...] Nova investida surge em julho do corrente ano, quando abruptamente os presos políticos foram removidos [...] para a Penitenciária do Estado. [...] Há 105 dias estão os presos políticos confinados em cubículos individuais sem nenhum dos direitos que a LSN lhes confere e sujeitos a toda sorte de provações [...]. Acresce ainda, a situação de absoluta restrição de visitas de familiares, recebimento de alimentos, agasalhos, leituras e a precariedade das condições de higiene. Contra tais fatos mobilizaram-se as famílias e os advogados. $[\ldots]$ que receberam promessas que não se concretizaram $[\ldots]^{10}$."

Na USP, os estudantes organizaram-se em apoio ao movimento, divulgando o manifesto e os nomes dos presos em greve. A BBC de Londres noticiou a greve como destaque do resumo das notícias mais importantes da semana. Havia brasileiros trabalhando lá com os quais os exilados mantinham contato regular (DEL ROIO, 2011); assim como na Anistia Internacional (JOSÉ, 2000). No terceiro dia de greve, o Papa Paulo VI pediu para que todos rezassem pelos 36 prisioneiros políticos em greve de fome no Brasil, em protesto contra os maus-tratos recebidos (SÁ, 2007, p.214).

Não obstante a censura imposta pela ditadura, a opinião pública brasileira tomou conhecimento da greve. Deputados do MDB denunciaram os maus-

\footnotetext{
${ }^{9}$ Cf. Fonte: <http://almanaque.folha.uol.com.br/ilustrada_05mar1978.htm>. Acesso em maio de 2014.

10 "Brasil: um panfleto sobre a tortura e o resto do 'milagre'", Expresso, 30 de novembro de 1974, p.8.
} 
tratos sofridos pelos presos políticos na Câmara Federal e no Senado. No quinto dia, chegou-se a um acordo, a greve seria suspensa desde que fossem transferidos para a Casa de Detenção, com a manutenção de todos os direitos conquistados anteriormente, e que seriam transferidos para um presídio exclusivo para presos políticos. Dois ou três dias depois, no dia 5 de novembro de 1974, os presos políticos foram transferidos novamente para a Casa de Detenção (IDEM, p.215-6), enquanto se ultimavam os preparativos para o presídio exclusivo para os mesmos.

Nesse mesmo período, outra greve de fome foi articulada pelos presos políticos transferidos para o presídio do Exército, na Fortaleza de Santa Cruz, em Niterói $(\mathrm{RJ})$ - criada no século XVI para a proteção da Baía da Guanabara $^{11}$. Esses presos vieram da Ilha Grande e da Vila Militar no continente, permanecendo confinados na Fortaleza por cerca de 9 meses (de março a novembro de 1974), em duas celas posicionadas em um inóspito buraco cavado na rocha, o qual era conhecido como "túnel velho". De acordo com os presos políticos, os militares tinham como objetivo estabelecer uma experiência com um sistema de premiações relacionado ao comportamento dos presos (REZENDE, 2000, p.126). Nossa pesquisa revela que este "experimento" foi provavelmente liderado pelo capitão e psiquiatra Arquimedes Correia Lima, que preconizou um sistema classificatório que, em tese, auxiliaria a reorganização do regime carcerário dos presos políticos, no contexto da implantação do projeto de abertura lenta, gradual e segura do general Geisel (TELES, 2011).

Na Fortaleza, as práticas remontavam ao período da escravidão. O castigo reservado aos que adotavam posturas de enfrentamento, por exemplo, era o confinamento nas "celas do passado", as quais tradicionalmente serviram para o aprisionamento de escravos condenados à morte. $\mathrm{O}$ confinamento dava-se em buracos escavados na pedra ("celas”), cujas alturas variavam de 0,70 a 1,80 metros. José Roberto Rezende e Claudio Torres da Silva permaneceram por sete dias presos nessas celas, como castigo contra um protesto de que participaram (REZENDE, 2000, p.127-30) ${ }^{12}$. Os presos protestavam contra o retorno de um preso político epilético e esquizofrênico nas celas

\footnotetext{
${ }^{11}$ A Fortaleza de Santa Cruz, inaugurada em 1555 por Nicolas de Villegaignon, teve papel relevante na defesa da Baía da Guanabara no período colonial.

${ }^{12}$ Nossa pesquisa sugere que a severidade da punição infligida relaciona-se com a participação deles em sequestros de diplomatas (respectivamente, do embaixador alemão e norte-americano).
} 
compartilhadas (Ubajara), posto que ele, tomado por crises psicóticas, havia tentado matar um companheiro de cela quando preso no continente e agredido outro na Fortaleza. A repressão contra o protesto iniciou-se com bombas de gás lacrimogêneo lançadas à distância para dentro das celas e com cacetadas desferidas a esmo.

Enquanto os dois presos mencionados foram encarcerados nas "celas do passado", os demais foram levados para as "solitárias". Nessa atmosfera, os presos trazidos da Ilha Grande (há mais tempo na Fortaleza) prepararam uma greve de fome com o objetivo de conseguirem sua transferência para o continente, conforme nos relatou Rômulo Noronha, militante da ALN preso em março de 1970 no Rio de Janeiro:

"Na Fortaleza de Santa Cruz, [...] soubemos depois que eles queriam criar três níveis de graduação de presídios: os dos recuperáveis, os irrecuperáveis e dos passíveis de recuperação.

[...] Quando nós fomos para lá, [...] não sabíamos para onde estávamos sendo levados. [...] saímos da mão da PM e ficamos nove meses sob a custódia do Exército brasileiro. [...] Ali foi o lugar onde estiveram presos escravos, onde esteve Andresito Artigas, um herói do Paraguai, Giuseppe Garibaldi etc. Um lugar que foi usado no período colonial como masmorra, como centro de tortura. Tanto que na Fortaleza de Santa Cruz tinha um lugar que chamavam de 'cova da onça', por causa dos gritos dos torturados que pareciam com o urro de uma onça, onde eles faziam o serviço completo. [...] Foi nesta prisão histórica, [...] que nós fizemos uma greve de fome [em novembro] que obrigou a uma intervenção do I Exército no comando da Fortaleza. [...] Eles queriam acabar com a nossa greve de fome, porque a pressão internacional foi grande. [...] acho que foram uns 9 dias de greve de fome ${ }^{13}$."

Esta situação extrema foi superada com uma greve de forme iniciada em novembro, próximo às eleições de 1974. A repercussão foi grande, as famílias e advogados enviaram telegramas para os ministros do STM e do STF, assim como para o comandante do I Exército e para o presidente Geisel. A OAB e a Cúria Metropolitana se manifestaram favoravelmente aos presos e a imprensa noticiou amplamente o fato (FERNANDES JR., 2004, p.250). O comandante

${ }^{13}$ Cf. ALBUQUERQUE (2010); REZENDE (2000, p.127-30). 
do presídio foi destituído ${ }^{14}$ e por meio da negociação intermediada pelo major Miranda, do QG do I Exército, os presos políticos foram enviados de volta para o continente, conquistando suas reivindicações. Eles retornaram ao Presídio Provisório Hélio Gomes, o "PP", e, em seguida, para o presídio da Ilha Grande (ALBUQUERQUE, 2010).

Nos estados do Rio de Janeiro e de Pernambuco, as famílias tinham muitos obstáculos a enfrentar para conseguir visitar os presos políticos, pois, em determinados períodos, eles ficaram confinados em presídios distantes dos centros urbanos, como o Presídio de Ilha Grande (RJ) (o que ocorreu até 1975) e a Penitenciária da Ilha de Itamaracá (PE) (até 1979).

Segundo Rômulo Noronha, o isolamento imposto pela distância do presídio da Ilha Grande dificultava enormemente as visitas dos parentes. Do Rio de Janeiro, as famílias tinham que se dirigir a Mangaratiba e de lá pegavam um barco para a ilha. O tempo de permanência permitido na ilha era curto, apenas 3 horas, pois, do contrário, perdiam o barco de volta. Quando havia uma tempestade, era necessário esperar o mar se acalmar para pegar outra embarcação, mas, naquela época, as pousadas não eram comuns na ilha, o que criava mais obstáculos aos visitantes, quando havia problemas desse tipo (REZENDE, 2000, p.132):

"No início, eu tinha visita só da minha mãe, porque a minha
companheira ainda estava sendo procurada, clandestina. As visitas
ocorriam a cada 21 dias e eram somente de familiares diretos. [...]
A Ilha Grande era isolada de tudo. [...] Depois conquistamos que as
visitas fossem a cada 15 dias, mas foi preciso fazer 3 greves de fome
lá para conquistar nossos direitos (ALBUQUERQUE, 2010)."

De acordo com o testemunho de Lúcia Murat, além da localização do presídio, havia outras dificuldades a serem enfrentadas, como as perseguições políticas que continuaram mesmo depois de sua libertação, em 1974. Havia também impedimentos de caráter afetivo, que frequentemente impactavam as relações amorosas dos presos, bem como o relacionamento espontâneo com as visitas. Lúcia relata ter perdido o emprego, ter sido ameaçada pelo CCC (Comando de Caça aos Comunistas) e optado por se mudar para o Rio

\footnotetext{
${ }^{14}$ Major Haroldo Magno do Nascimento (Infantaria do Exército) comandou a Fortaleza de Santa Cruz entre 1971 e 1974. Disponível em: <http://www.desaparecidos.org/brazil/tort/ pequena.html $>$. Acesso em: 10 de dezembro de 2012.
} 
Grande do Sul (onde passou 6 meses), afastando-se do namorado, Claudio Torres da Silva ${ }^{15}$, que permanecia preso na ilha (MURAT, 2010, p.392-393).

Apesar de todas as dificuldades, é interessante notar a profusão e vividez de relatos sobre os encontros e trocas de informações e experiências ocorridas nas visitas. Delas surgiram casamentos, filhos e muitos planos, envolvendo advogados, padres, artistas, cantores, políticos, que deste modo contribuíram para a amplificação dos vínculos com o "mundo exterior" e o próprio poder da rede de solidariedade e apoio aos presos políticos no Brasil.

\section{A conquista dos presídios políticos}

Os abalos sofridos pelo regime com o colapso do "milagre econômico" e a derrota nas eleições de novembro de 1974 levaram a imprensa alternativa a assumir uma nova dimensão, caracterizada pelo aumento de sua influência e do poder de divulgação das lutas populares e de denúncias dos abusos aos direitos humanos cometidos pela ditadura. A imprensa alternativa tornouse a expressão e parte fundamental de articulação da resistência à ditadura (KUCINSKI, 2003, p.94), consolidando-se como um lugar de atuação da militância partidária e, inclusive, espaço para empregar ex-presos políticos.

Nesta conjuntura, em 4 de março de 1975, os presos políticos inauguraram o presídio Romão Gomes, no Barro Branco, na zona norte de São Paulo (MORANO FILHO, 2002). Embora fosse administrado pela Polícia Militar, oferecia melhores condições carcerárias e era composto exclusivamente por presos políticos. Uma nova fase de adaptação e convívio se iniciava para os presos transferidos para este presídio, onde conseguiram se organizar melhor e ampliar seus contatos políticos.

Em 5 de maio, os presos políticos da Ilha Grande iniciaram uma greve de fome de 17 dias, a qual teve grande cobertura da imprensa e apoio. Artistas famosos escreveram ao STM solicitando a transferência dos presos; parlamentares do MDB leram no Congresso moções de apoio à sua luta. A CNBB também buscou a adesão de políticos e ministros do STM. Terminada

\footnotetext{
${ }^{15}$ Dirigente do MR-8 (DI-GB) que participou do sequestro do embaixador norte-americano em setembro de 1969. Preso dois dias depois da libertação do diplomata, ele foi solto em setembro de 1976 (DA-RIN, 2008, p.288).
} 
a greve vitoriosa, em junho começaram a ser transferidos para o presídio Esmeraldino Bandeira, em Bangu. A partir de fevereiro de 1976, passaram a ocupar uma ala exclusiva na penitenciária Lemos de Brito, na rua Frei Caneca, mantendo suas conquistas (FERNANDES JR., 2004, p.278-81). Desde 1971, através de muita luta e greves de fome, os presos da ilha conquistaram, inclusive, o direito a visita conjugal. As celas eram coletivas, assim, estabeleceram escalas de horários e muitos começaram relacionamentos duradouros na cadeia ${ }^{16}$.

Ainda no mês de julho de 1975, os presos políticos da Penitenciária Professor Barreto Campelo, localizada na ilha de Itamaracá, em Recife, deflagraram uma greve de fome contra a transferência de alguns presos para quartéis no continente. A greve durou 15 dias e cessou depois que os presos conseguiram o compromisso formal do Superintendente do Sistema Penitenciário de Pernambuco de que suas reivindicações seriam atendidas ${ }^{17}$.

No final do mês de outubro, os presos do presídio Romão Gomes, em São Paulo, conseguiram burlar a segurança e fizeram sair um documento de denúncia das torturas e assassinatos do regime, durante uma visita de D. Paulo E. Arns. A iniciativa era uma resposta a uma declaração do presidente do Conselho Federal da OAB, Caio Mário da Silva Pereira, que lamentava não ter conseguido dados objetivos, por parte das vítimas, sobre prisões irregulares e arbitrariedades policiais, conforme publicado na Folha de $S$. Paulo do dia 1 de agosto daquele ano.

$\mathrm{Na}$ introdução do texto, os presos manifestaram sua intenção de fornecer um relatório objetivo acerca dos crimes cometidos pelos órgãos de segurança e informação ao Conselho Federal da entidade, com o fim de que não ficasse nenhuma dúvida e fosse realizada a devida apuração dos mesmos:

"Embora cientes das muitas denúncias concretas já havidas -
inúmeras delas inclusive divulgadas mais recentemente por jornais
brasileiros -, vimo-nos na obrigação, como vítimas, sobreviventes
e testemunhas de gravíssimas violações aos direitos humanos no
Brasil, de encaminhar a V. Sa. um relato objetivo e pormenorizado
de tudo o que nos tem sido infligido, nos últimos seis anos, bem

${ }^{16}$ Cf. REZENDE (2000), p.134; e CIPRIANO (1992, p.38).

${ }^{17}$ Cf. SOARES (2010) e MELO (2009; 2010). 
como daquilo que presenciamos e acompanhamos pessoalmente dentro da história recente do país. [...] É possível que, a despeito de nosso cuidado na elaboração deste texto incorramos em algumas pequenas imprecisões [...]. Fizemo-lo preocupados com a exatidão dos fatos narrados e dispomo-nos a testemunhar perante qualquer comissão ou tribunal idôneo - e realmente interessados em apurar o que aqui se descreve -, quanto ao que relatamos (COMITÊ, 1976, p.160-4)”.

Os presos denunciaram a política de ocultação de cadáveres e de desaparecimentos forçados e a resposta mentirosa do ministro da Justiça, Armando Falcão, dirigida em fevereiro de 1975 aos reclamos dos familiares para esclarecer estes casos, o que acabou gerando a "Crise dos Desaparecidos" e o veto à constituição da CPI dos Direitos Humanos (TELES, 2005). Fizeram um histórico das greves de fome de que participaram em São Paulo e as que ocorreram em outros estados, visando melhorias nas condições carcerárias. E denunciaram que, novamente, os presos políticos de Pernambuco estavam em greve de forme em função do não cumprimento do acordo feito após a greve realizada no mês de julho.

Por fim, o texto faz uma ampla descrição dos métodos e instrumentos de tortura, acompanhado do levantamento dos nomes de 233 torturadores - a lista nomeava os indivíduos que participaram diretamente das sessões de tortura dos que os denunciavam ou aqueles cuja atuação tivesse sido testemunhada pessoalmente por eles (COMITÊ, 1976, p.160-90). Em seguida faz uma apresentação do funcionamento dos órgãos repressivos, das irregularidades jurídicas praticadas contra os presos políticos, mostrando que nem as leis de exceção eram cumpridas, e das condições carcerárias de cada presídio. E ao final traz uma detalhada descrição de 16 casos de perseguidos políticos assassinados sob tortura, presenciados por eles, entre os quais os de dois guerrilheiros desaparecidos na Guerrilha do Araguaia. A seguir, descreveram 19 casos de desaparecidos políticos, citando o abaixoassinado enviado ao STM em 18 de fevereiro de 1975 em protesto à resposta de Armando Falcão às solicitações dos familiares de desaparecidos.

O documento também apresenta uma lista com os nomes de outros 20 presos políticos assassinados sob tortura, considerados desaparecidos. Detalharam ainda os casos de desaparecimento de Fernando Santa Cruz e Eduardo Collier, Joaquim Pires Cerveira e Edgar Aquino Duarte. Os casos de presos que tiveram sequelas físicas e psíquicas são citados, entre eles o de Frei Tito Alencar, que havia se suicidado pouco mais de um ano antes. 
Ao final, o documento ressalta o fato desses assassinatos não serem práticas do passado e fazem menção às notícias de jornais sobre militantes do PCB assassinados em 1975; entre eles dois presos integrantes da Policia Militar de São Paulo. Poucos dias depois de terminado, o documento recebeu um adendo, onde os presos acrescentaram a denúncia do assassinato sob tortura de Vladimir Herzog, no dia 25 de outubro (IDEM, p.224-27) ${ }^{18}$.

Esta denúncia foi redigida e assinada por 35 presos políticos do presídio Romão Gomes e enviada oficialmente para a $\mathrm{OAB}$, através do advogado Luiz Eduardo Greenhalgh. Dom Paulo se preocupava com o aspecto legal das denúncias que chagavam a ele, assim, foi elaborada uma estratégia para fazer com que o documento fosse entregue a ele sem despertar suspeitas. Durante uma reunião realizada com uma comissão de presos na sala reservada às visitas com os advogados no presídio, o arcebispo de São Paulo recebeu a carta contendo as denúncias ${ }^{19}$, trazido dentro de uma garrafa térmica com café. Cópias do documento foram enviadas para jornais, entidades e personalidades por familiares e militantes (TELES, 2013), as quais ganharam certa repercussão.

Em seguida, deu-se a reação ao assassinato do jornalista e militante do PCB, Vladimir Herzog. Em represália ao documento, os presos receberam cartas e telefonemas anônimos contendo ameaças e José Genoino foi transferido para o presídio de Fortaleza, com o objetivo de isolá-lo.

Paralelamente, o presidente da $\mathrm{OAB}$ encaminhou a denúncia dos presos políticos ao ministro Chefe da Casa Civil Golbery do Couto e Silva por meio de uma representação no dia 26 de novembro. A iniciativa não teve desdobramentos, conforme ocorrera em 1974 quando os familiares de mortos e desaparecidos se reuniram com Golbery e D. Paulo E. Arns, o que acabou gerando grande decepção e a "Crise dos Desaparecidos". Não obstante, o SNI a considerou

“[...] mais uma tática do MCI [Movimento Comunista Internacional] para desmoralizar e intimidar os órgãos de segurança, visando à sua neutralização atual e extinção futura. [...] Com apoio de D. Hélder Cämara, essa campanha alcançou repercussão no exterior, onde passou a ser patrocinada pela Amnesty International, entidade que

\footnotetext{
${ }^{18}$ V. tb. Almeida (2009, p.616-18, p.621-22).

${ }^{20}$ MORANO FILHO (2008; 2009) e MARTINS (2009). .
} 
assumiu a liderança dessas difamações, visando ao descrédito do nosso país. [...] O objetivo imediato visado é o de dar continuidade à campanha no sentido de pressionar os órgãos de segurança, criando um clima para, no futuro, e, se possível, levar ao banco dos réus os integrantes mencionados ${ }^{20}$."

Em documento elaborado pelo SNI ao presidente Ernesto Geisel, os militares revelaram preocupação com a denúncia, pois a cada divulgação deste tipo se criava uma atmosfera de "apreensão e desestímulo" no interior dos órgãos de segurança. As denúncias ainda os obrigavam a preparar "respostas esclarecedoras" à opinião pública. No texto, a comunidade de informações reafirmou seu respeito à hierarquia militar à semelhança de uma advertência: "[...] cabe considerar que os elementos componentes dos Destacamentos de Operações Internas sempre atuaram no cumprimento das ordens emanadas dos escalões superiores (IDEM)."

Em janeiro de 1976, a Folha da Tarde dedicou uma página inteira do jornal aos presos políticos, na qual se referia ao documento dirigido ao presidente do Conselho Federal da OAB. Em março, as Auditorias Militares de São Paulo expediram o ofício, dirigido ao capitão-diretor do presídio, instituindo uma nova fase de censura a livros e revistas, infernizando suas vidas quanto ao recebimento de publicações por ele julgada de cunho político. Em setembro, novamente os presos receberam ameaças anônimas.

Neste período, a situação dos presos era incerta. Avanços e retrocessos sucediam-se e entremeavam-se de maneira pouco padronizada, ao sabor das conjunturas locais em seu enlace com o panorama mais amplo do país. O "Pacote de abril" deu a tônica deste período, no qual o congresso nacional foi fechado por um período significativo, e os militantes dividiamse entre perspectivas menos e mais ofensivas com relação à divulgação das denúncias dos crimes da ditadura e condições carcerárias vividas pelos presos políticos.

Sob este panorama ambíguo, os presos políticos da penitenciária Barreto Campelo, em Itamaracá (PE), iniciaram uma greve de fome em protesto

\footnotetext{
${ }^{20}$ Nesse momento, Heleno Fragoso, um conhecido defensor de presos políticos, era o vicepresidente da OAB. A entidade e seus dirigentes encontravam-se monitorados pelo SNI, conforme documentos de 1976 encontrados em 2013. Cf. Marsílea Gombata. A paranoia dos algozes. 26 de dezembro de 2013. Disponível em <http://www.cartacapital.com.br/revista/779/ a-paranoia-dos-algozes-1879.html>. Acesso em 15 de fevereiro de 2014.
} 
contra o isolamento a que estavam submetidos os presos Rholine Sonde Cavalcanti e Carlos Alberto Soares, os quais haviam sido condenados à prisão perpétua e estavam isolados do convívio com os outros há mais de três anos (JOSÉ, 2000, p.259). O movimento durou 17 dias e ganhou grande repercussão e solidariedade nacionais.

$\mathrm{O}$ uso de greves de fome como mecanismo de reivindicação e protesto nem sempre atingiu a mesma eficácia. Em 1977, por exemplo, ocorrem duas greves de fome em solidariedade aos dois presos supramencionados, que não lograram êxito, o que nos sugere que as articulações entre os presos políticos ainda era incipiente, ao mesmo tempo em que expandia-se o interesse da sociedade para sua realidade e para as novas possibilidades de ampliação de sua luta.

Já em 16 de abril de 1978, um movimento mais amplo iniciou-se no Presídio Campelo Barreto contra o isolamento de Rholine e Carlos Alberto, dando origem à primeira greve de fome nacional do período ditatorial. $\mathrm{O}$ movimento grevista contou com expressiva solidariedade tanto no país como no exterior - desde a CJP/PE e a CNBB a ABI, o MFPA e políticos do MDB.

O secretário geral da Anistia Internacional, Martin Ennals, e a representante da entidade, Patrícia Freeneym, enviaram telegramas ao presidente da República e ao almirante Hélio Leite, presidente do Superior Tribunal Militar, apelando para que interviessem na greve de fome dos presos políticos de Itamaracá ${ }^{21}$.

A greve de fome nacional teve como aspecto-chave a adesão dos 26 presos políticos do Presídio Frei Caneca, no Rio de Janeiro, no dia 25 de abril, a qual foi seguida pela adesão das duas presas do Presídio Talavera Bruce, no Rio de Janeiro.

A participação dos presos políticos de São Paulo foi discreta ${ }^{22}$. Na tarde do dia $1^{\circ}$ de maio, 18 presos do Presídio Político Romão Gomes entraram em greve de fome em solidariedade ao movimento grevista de Itamaracá. Três deles, embora solidários, não aderiram por motivo de saúde ${ }^{23}$. No dia 5 de

\footnotetext{
21 "Anistia apela a Geisel pelos presos de Recife". Folha de S. Paulo, 28 de abril de 1978, p.8.

${ }_{22}$ Manoel Cyrillo Netto relatou-nos que não se recorda como foi a greve de fome de 1978, cf. NETTO (2009; 2010).

23 "A greve de fome recebe adesão de presos paulistas". Folha de S. Paulo, 02 de maio de 1978, p.7.
} 
maio, os 10 presos políticos de Fortaleza (CE) também entraram em greve de fome ${ }^{24}$.

Em seguida, uma comitiva composta de 30 familiares de presos políticos do Estado de São Paulo foi para Brasília, onde visitou o Congresso e o presidente do STM, e tentou encaminhar uma carta ao presidente Geisel solicitando a sua intervenção para que as reivindicações dos presos em greve fossem atendidas. A viagem foi antecipada em virtude do estado de saúde de alguns dos presos ter se agravado ${ }^{25}$.

Ao mesmo tempo, dois mil estudantes da Faculdade de Filosofia da UFMG, em Belo Horizonte, entraram em greve, em solidariedade aos presos políticos em greve de fome, enquanto em Olinda, dom Helder Câmara, presidiu uma vigília de orações, que teve início às 20 horas do dia 8 de maio. $\mathrm{O}$ mesmo ocorreu em São Paulo, onde uma vigília de solidariedade convocada pelo CBA reuniu 700 pessoas.

Os familiares percorreram os gabinetes oficiais do Palácio do Planalto, do Supremo Tribunal Militar, do Ministério da Justiça e das lideranças da Câmara e do Senado sem encontrar soluções para o problema que enfrentavam havia 22 dias, e, invariavelmente, ouviram a mesma desculpa das autoridades: "O assunto não diz respeito a esta área"26.

Os 25 presos políticos de Itamaracá, em Recife, terminaram no dia 9 de maio a greve de fome que mantiveram por 24 dias. A decisão foi tomada após a mediação do deputado federal Airton Soares, presidente da Comissão de Direitos Humanos do MDB, que lhes revelou a promessa feita pelo auditor José Bolívar Regis, da 7ª Circunscrição da Justiça Militar, de que em uma semana atenderia parcialmente as reivindicações dos presos políticos ${ }^{27}$. Marcelo Mário de Melo contou como ocorreu o desfecho da greve de fome:

"Houve uma negociação localizada em Itamaracá e a gente achou que dava para terminar a greve. Efetivamente, depois, houve um compromisso de que eles [Rholine e Carlos Alberto] tivessem, pelo menos, o direito de ter um convívio de quatro dias da semana com a gente. [...] e aí eles passaram a vir nos encontrar. E, um dia, depois desse processo, devolveram os dois pra gente e pronto, passou. Foi uma conquista, fruto desse processo de luta.

\footnotetext{
25 "Presos do Ceará aderem à greve". Folha de S. Paulo, 02 de maio de 1978, p.8.

26 "Estado de saúde dos grevistas já preocupa médicos". Folha de S. Paulo, 08 de maio de 1978, p.4.

27 “Os 15 presos suspendem a greve de fome (ontem).” Folha de S. Paulo, 10 de maio de 1978, p.1.
} 
[...] Mas quando houve a negociação do fim da greve e o convívio dos dois foi acertado, já havia sido marcado um ato de solidariedade aos presos políticos, parece-me que numa faculdade do Rio. O negócio ia ser arretado, mas precisaria de mais uns quatro dias de greve. Aí alguns companheiros disseram o seguinte: '- A greve deixou de ser específica de presos políticos contra o isolamento de Rholine e Carlos e passou a ser de luta contra a ditadura'. Eu e outros companheiros, que predominaram, dissemos: '- Não, a greve continua a ser por um objetivo específico [...]. Engrossou o caldo da solidariedade, ótimo, a vigília que está marcada passará a ser uma vigília de festa, de comemoração. Temos que encerrar agora [...]'. Foi aprovada esta posição, mas os companheiros que defenderam a outra disseram que foi capitulação, estreiteza, que nós não estivemos à altura do momento histórico.

[...] Era artificial querer dar uma injeção na greve. [...] O clima ficou péssimo, uma greve vitoriosa que incorporou o movimento popular do Brasil todo, mas o clima dentro da cadeia era de enterro $[\ldots]$. A ponto de $[\ldots]$ quererem uma entrevista nossa $[\ldots]$ e nós não tivemos condições de dar, porque não havia consenso. [...] Houve uma grande insatisfação de companheiros importantes, expressivos. [...] mas foi ótimo (MELO, 2009; 2010)”.

\section{A luta pela anistia e as denúncias}

A luta pela anistia tem como marcos iniciais ações promovidas pela rede de solidariedade dos presos políticos, fundamentalmente sustentada pelas mulheres, através do Movimento Feminino pela Anistia, e pela igreja católica progressista, sobretudo através da atuação de dom Paulo Evaristo Arns. Este movimento recebeu uma acolhida inicial ambígua entre os presos, cuja dinâmica de adesão e resistência entremeou-se às estratégias de denúncia, entre 1975 e 1977.

Especificamente, a ambiguidade relacionava-se às concepções distintas acerca do papel da sociedade civil que, para alguns presos, deveria ser o locus a partir do qual o movimento da anistia deveria se desenvolver, ao contrário do que pensavam outros, afeitos a encampar esta bandeira. É de se ter em vista que tal situação também refletia a percepção de muitos de que não haviam cometido qualquer tipo de ato criminoso ou ilegítimo, de modo que não haveria nada para ser anistiado de sua parte. Os principais entusiastas da campanha da anistia eram os familiares, estudantes e advogados. 
No presídio Romão Gomes, em São Paulo, havia posições divergentes entre os presos sobre quais conteúdos e consequências políticas envolviam a luta pela anistia, se ela implicaria num projeto de transição política com hegemonia da proposta de conciliação com setores que apoiaram a ditadura e o sistema repressivo. Havia presos que desde o primeiro momento abraçaram com força a ideia da anistia, e outros que, inicialmente, foram refratários à proposta, conforme relato de Pedro Rocha:

“[...] Para alguns, talvez, a anistia significasse o fim, terminou a luta agora estamos no momento da reconciliação, então, vamos partir para a luta pela anistia. Para outros não tinha esse significado, ela fazia parte da luta democrática. [...] existiam diversas visões. O concreto é que a partir de um determinado momento todo mundo abraçou a luta pela anistia e contribuiu do jeito que foi possível, principalmente, com documentação, inclusive, teórica [...]. Muita documentação em relação à anistia foi elaborada dentro da prisão e foi mandada para fora (ROCHA, 2010).”

Com o tempo, os presos passaram a apoiar a campanha em defesa da anistia, com a intenção de interferir no processo de luta e tentar mudar a correlação de forças no cenário político nacional. Um dos aspectos mais polêmicos a respeito de qual proposta apoiar estava relacionada à abrangência da anistia, era preciso convencer diversos setores das oposições de que os presos políticos que participaram da luta armada deveriam ser contemplados.

A edição do Pacote de Abril em 1977 e as tensões acumuladas com o fortalecimento dos movimentos sociais levaram os estudantes universitários às ruas em protesto contra as prisões de operários e estudantes trotskistas, às vésperas do $1^{\circ}$ de maio.

No dia 28 de abril seis pessoas, estudantes e operários, foram detidas nas proximidades da fábrica da General Motors, na região do ABC paulista, acusadas de distribuir panfletos "subversivos". Os presos eram militantes da organização trotskista Liga Operária, que originou a Convergência Socialista $^{28}$. O então secretário de Segurança de São Paulo, Erasmo Dias,

${ }^{28}$ Cf. BRAMBILLA (2009) e PAES (2009); "Explicação para prisões no ABCD”. Folha de S. Paulo. 01 de maio de 1977, p.33. Cf. http://acervo.folha.com.br/fsp/1977/5/1/387/4239086>. Acesso em 12/03/12; "Novas figuras na política”. Veja, 11 de maio de 1977, p.22. 
procurou ligar o grupo à luta armada tentando justificar a brutalidade do tratamento dado aos presos $^{29}$.

No dia 5 de maio, outra manifestação convocada pelos estudantes aconteceu no centro da cidade, em protesto contra a prisão dos presos do $\mathrm{ABC}$, reunindo cerca de 7 mil pessoas, quando houve enfrentamento com a polícia. Os protestos contra as prisões do ABC estimularam a ampliação das demandas do movimento estudantil e a 'questão democrática' emergiu com força, dando um conteúdo mais politizado às manifestações (NAPOLITANO, 2005, p.34-36). O movimento passava por um processo de renascimento e politização. Esta movimentação impulsionou as lutas em defesa da anistia para os perseguidos políticos.

Nessa conjuntura de crescimento da crise de legitimidade da ditadura surgiram os Comitês Brasileiros de Anistia (CBA), que lançaram e impulsionaram a Campanha pela Anistia ampla, gerale irrestrita. Um movimento eminentemente político que recebeu certo apoio popular e cuja adesão foi mobilizada pela extensa divulgação pública das denúncias a respeito dos crimes cometidos pela ditadura (TELES, 2005).

Em 12 de maio de 1978 eclodiram as primeiras greves operárias desde 1968, partindo de um movimento autônomo em relação às organizações tradicionais das esquerdas (KUCINSKI, 2003, p.384-8). O processo de abertura escapava ao controle dos militares. Em junho acabou a censura prévia nos últimos três veículos ainda submetidos a ela, a Tribuna da Imprensa, O São Paulo e Movimento, marcando um momento importante para o fim do autoritarismo na atividade jornalística. Iniciaram-se, nesse período também, as greves dos professores da rede pública de ensino.

Os jornais alternativos se destacaram pela cobertura sobre a luta pela anistia. O Em Tempo desde os primeiros números também deu atenção à campanha. A edição de número 3 possui várias manchetes sobre o tema e uma, em especial, destacava: "Todos de volta até o natal". A edição de no. 17, de junho de 1978, estampou na manchete "Presos denunciam 233 torturadores" ${ }^{\prime 30}$. A reportagem divulgava o documento elaborado pelos 35 presos políticos do Romão Gomes, em 1975. Na capa aparecem destacados os nomes dos torturadores mais conhecidos: delegado Fleury, general Antonio

\footnotetext{
29 "Novas figuras na política". Idem.

${ }^{30}$ Em Tempo, n. 17, 28 de junho a 02 de julho de 78, p.6-7.
} 
Bandeira, os delegados mineiros David Hazan e Tacir Menezes Sia e o deputado federal arenista Ivahyr de Freitas Garcia. Destacava na capa a frase dos presos políticos: "Estamos dispostos a testemunhar perante qualquer comissão ou tribunal idôneos, tudo quanto relatamos" (IDEM), antecipando a retomada da proposta de CPI dos Direitos Humanos de 1975.

$\mathrm{O}$ clima em relação às informações trazidas à tona pelos militantes e jornalistas era controverso. Por exemplo, Bernardo Kucinski - que deixara de ser editor do Em Tempo em março - afirmou em entrevista que, na época, não havia dado a devida importância para a sugestão da matéria, posto que considerava que a lista deveria ser checada antes que a ela se atribuísse credibilidade (KUCINSKI, 2012). Segundo o próprio, ele estava enganado: aquela edição do jornal atingiu seu apogeu de vendagem (IDEM, 2003, p.418-19) ${ }^{31}$.

Isso valeu ao jornal represálias: três atentados de grupos paramilitares de extrema direita, que levaram à depredação e à explosão de uma bomba em algumas sucursais. A matéria recebeu duras críticas de setores da oposição democrática, os quais a consideravam uma provação, enquanto os governistas a taxavam de "revanchista". O jornal, porém, reafirmou sua disposição de continuar incentivando a investigação em busca de denúncias ${ }^{32}$. Os movimentos em defesa da anistia ampla, geral e irrestrita colocavam em pauta na cena pública a luta para esclarecer os crimes da ditadura.

Os bons resultados do MDB nas eleições de 1974 e 1976 atraíram vários grupos de esquerda para as eleições nacionais de 1978. Aproveitaram-se do espaço aberto e a cobertura legal fornecida pelo MDB, uma das poucas instâncias onde a atividade política era possível após a derrota das esquerdas revolucionárias. Nesse período, diversos militantes voltaram ao país clandestinamente para retomar a atividade política. Assim, vários grupos $\mathrm{e}$ partidos clandestinos como PCB, PC do B, a Ação Popular (AP) e o MR-8 apoiaram candidatos do grupo dos autênticos do MDB, ativistas políticos diretamente ligados a movimentos populares ou candidatos próprios nessas eleições. Conforme nos relatou o ex-preso político e exilado Ricardo Azevedo, dirigente da Coordenação Nacional da AP naquele período:

\footnotetext{
${ }^{31}$ Segundo um jornalista da equipe do Em Tempo (que preferiu não ser identificado), a redação tinha um documento datilografado com a lista dos 233 torturadores. Ao buscarem obter mais informações, chegou-se ao livro Presos políticos brasileiros: acerca da repressão fascista no Brasil (1976). Cf. MELO (2011).

32 "Dos 233 aos 442". Em Tempo, n. 54, 8 a 14 março de 1979, p.5.
} 
“[...] Em 1974, [...] a AP mudou de tática e resolveu participar do processo eleitoral através do MDB, o que lhe deu uma audiência muito mais ampla do que o que ela tinha na clandestinidade defendendo o voto nulo. Mais do que isso, em 1976 a AP também participou [...] e, em 1978, elegeu o Geraldo Siqueira deputado estadual em São Paulo e o José Eudes deputado estadual, no Rio de Janeiro. Então, isso deu um crescimento para a organização muito grande. [...] Com isso a AP ganhou uma sobrevida, então, ela se reorganiza, cresce em termos relativos, embora com pouca penetração no movimento operário (AZEVEDO, 2010)”.

$\mathrm{O}$ voto de protesto mudou a composição das bancadas do MDB, que consolidou e ampliou sua posição, obtendo $47 \%$ dos votos para o Senado (42\% em 1974) e 39,3\% dos votos para a Câmara Federal (38\% em 1974). O grupo autêntico do MDB dobrou de tamanho, passou a ter cerca de noventa deputados na Câmara Federal. Cerca de duas dezenas de deputados federais se elegeram apoiados pelos partidos da esquerda clandestina. O partido conquistou ainda a maioria nas assembleias legislativas dos estados do Rio de Janeiro, São Paulo e Rio Grande do Sul (KUCINSKI, 2001, p.74).

A ênfase do debate em muitos grupos de militantes e exilados era a articulação pela formação de um partido à esquerda do MDB e de um movimento autônomo dos trabalhadores, sendo que parte das esquerdas dava destaque à bandeira da convocação da Assembleia Nacional Constituinte (KUCINSKI, 2003, p.423). As questões em debate para setores focalizavam a maneira de acumular forças para poder propor e interferir na construção política que sobreviria ao fim da ditadura.

Este cenário impulsionou a campanha pela anistia ampla, geral e irrestrita no ano de 1979. A efervescência da sociedade civil crescia, mas no início do mandato do general João Batista Figueiredo na presidência, a ditadura buscava retomar o controle do processo de abertura política.

O movimento de anistia percebendo o impulso adquirido, após a realização do Congresso da Anistia de novembro de 1978, na PUC/SP, traçou suas prioridades de ação visando à ampliação do seu leque de alianças. Lançou uma campanha nacional "para a recuperação da memória dos mortos e desaparecidos políticos pela repressão desde 64" no fim de janeiro de $1979^{33}$; e intensificou a preparação de lista detalhadas de mortos e desaparecidos

33 “CBA lança campanha por mortos e desaparecidos". Folha de S. Paulo, 10 de janeiro de 1979. 
políticos e a articulação da frente parlamentar pela anistia. Neste mês ocorreu outra célebre missa na Catedral da Sé, celebrada por D. Paulo, lançando a campanha pelo esclarecimento de 28 casos de desaparecimentos políticos. As fotos destas vítimas foram publicadas em um cartaz que trazia no alto a frase "Procura-se", ironizando a inversão do papel das forças repressivas naquele momento em que alguns segmentos tradicionais da sociedade começavam a manifestar a coragem de sugerir que deveriam estar no banco de réus.

No dia 05 de março, uma caravana de cem pessoas representativas de vários CBAs do país dirigiu-se ao Congresso Nacional levando a Carta Aberta da Comissão Executiva Nacional do movimento, o Dossiê dos Mortos e Desaparecidos e os dois documentos elaborados pelos presos políticos do presídio Romão Gomes/SP contendo denúncias de torturas e assassinatos. Foi entregue também um memorandum exigindo o esclarecimento dos casos de desaparecidos e a atribuição de responsabilidades dos crimes cometidos durante a ditadura. Reivindicava-se a constituição de uma CPI para apurar os crimes do regime ${ }^{34}$.

$\mathrm{Na}$ ocasião, o MDB assumiu publicamente a proposta de formação de uma frente parlamentar em torno da bandeira de anistia ampla, geral $e$ irrestrita. $\mathrm{O}$ movimento defendia que a conquista da anistia deveria expressar a manifestação soberana da vontade popular, mas não excluía a extensão da luta ao parlamento. No referido documento, afirmava-se o apoio à aprovação da emenda constitucional proposta pelo MDB, de autoria do senador Nelson Carneiro e do deputado Ulysses Guimarães, que determinava a reabilitação da prerrogativa do Congresso de propor o instituto da anistia (GRECO, 2003, p.106-8).

Neste contexto, foi publicada uma segunda matéria de capa do jornal $\mathrm{Em}$ Tempo sobre os torturadores, na segunda semana de março de 1979, com a seguinte chamada "Saiu o 2º listão: 442 torturadores" 35 . A matéria atribuía a criação da lista ao mesmo Comitê de Solidariedade aos Revolucionários Brasileiros, o qual havia elaborado a denúncia apresentada no Tribunal Bertrand Russell (tal comitê foi inventado pelos presos, conforme assinalado anteriormente), que fora divulgada na Europa a partir de 1976.

\footnotetext{
34 "Mão estendida, mas manchada de sangue". Em Tempo, n. 54, 8 a 14 mar. 1979, p.3.

35 “O listão dos torturadores". Em Tempo, n. 54, n. 54, 8 a 14 março de 1979, p.4-6.
} 
A lista elaborada pelo Comitê em 1974 recebeu um complemento contendo mais 114 nomes de agentes do aparato repressivo numa reunião que teria sido realizada em fevereiro de 1975. Os nomes contidos na lista integravam um relatório sobre a repressão política enviado à CNBB. Ao final do texto, os presos assinalavam a autoria coletiva da denúncia, destacando as contribuições recebidas desde a elaboração da primeira lista (COMITÊ, 1976, p.156). A derradeira autoria da lista de 442 torturadores, porém, permanece em debate ${ }^{36}$.

Em Tempo novamente deu destaque à seção do documento que nomeava os agentes repressivos, a despeito das ameaças dos grupos anticomunistas e das críticas de setores da esquerda, que consideravam imprudente fazêlo naquela conjuntura. $\mathrm{O}$ jornal tinha como horizonte a responsabilização judicial dos agentes da repressão estatal, por considerá-la passo fundamental para desmontar o aparato repressivo de então:

“[...] por acreditar que a luta por liberdades democráticas em nosso país não pode prescindir da exigência da desarticulação, do desmantelamento de todo o aparelho, de toda a máquina legal e clandestina, montada para reprimir, torturar e [...] matar os que fizeram oposição ao regime nestes últimos quinze anos. E para isso [...], os homens que movimentam esta poderosa máquina [...] precisam ser conhecidos por toda a população, aos culpados pela violência antipopular só pode restar a punição ${ }^{37}$ ”.

No dia seguinte, a 9 de março de 1979, a edição do jornal foi apreendida pela Polícia Federal em todo o território nacional. A medida revela uma mudança na estratégia repressiva que vinha ocorrendo naquele momento: os atentados e ameaças de grupos de ultra-direita estavam sendo substituídos pela apreensão dos jornais alternativos, considerada um método "menos bárbaro"38 e menos ostensivo. A apreensão do número 54 do semanário representou um prejuízo de 30 mil cruzeiros.

Neste período, contudo, Em Tempo estava enfrentando mais uma dissidência interna e uma grave crise econômica, acumulava uma dívida de

\footnotetext{
${ }^{36}$ Os entrevistados neste estudo não se recordam como a lista foi ampliada, cf. VIANA (2011) e NETTO (2011).

37 Em Tempo, n. 54, 8 a 14 de março de 1979, p.5.

38 Em Tempo, n. 55, 15 a 21 de março de 1979, p.3.
} 
1 milhão de cruzeiros, vendendo apenas 7 mil exemplares de uma tiragem de 28 mil. Passa a ser quase exclusivamente um porta-voz da Democracia Socialista (DS). Aos poucos, Em Tempo e os "jornais nanicos" deixaram de ser uma frente jornalística das esquerdas e perderam seu fôlego investigativo.

A proposta de retomar a prerrogativa do Congresso de propor a anistia foi rejeitada por uma comissão mista de senadores e deputados, no dia 18 de abril. Naquele dia, os CBAs de todo o país comemoraram o Dia Nacional da Anistia, data em que a anistia foi concedida, após o fim da ditadura de Getúlio Vargas, em $1945^{39}$. Coube ao Executivo, então, a iniciativa de apresentar o projeto de lei de anistia, no final de junho de 1979.

Outras listas sucederam-se a estas, durante a campanha da anistia. No mesmo dia 18 de abril, os presos políticos do Centro de Detenção Milton Dias Moreira, do Rio de Janeiro, divulgaram um documento enviado à OAB, CNBB, ABI, Comissão de Direitos Humanos do MDB, CBA e ao MFFA e demais entidades voltadas à defesa dos direitos humanos no Brasil e exterior. No documento fazem uma minuciosa análise de sua situação no presídio, na justiça militar, e também um amplo levantamento dos nomes e as circunstâncias de morte ou desaparecimento de militantes perseguidos pela repressão estatal, assim como de listas de torturadores, subdivididas em 3 categorias: aqueles que os haviam torturado diretamente; aqueles que presenciaram torturando; e ainda os nomes daqueles sobre os quais ouviram testemunhos de outros presos. Nestas listas aparecem 251 nomes, na qual muitos repressores do Rio de Janeiro são citados, inclusive, nomes de torturadores da Fortaleza de Santa Cruz (DIAS, 1979, p.74-77).

Em maio de 1979, Em Tempo voltou a divulgar denúncias de violações de direitos humanos, desta vez, publicou trechos do relatório escrito por 14 presos políticos do Rio de Janeiro. Intitulado "O nosso testemunho", o documento relatava 29 métodos de tortura utilizados contra os autores, 40 casos de assassinatos e desaparecimentos forçados, bem como um levantamento parcial dos desaparecidos na Guerrilha do Araguaia, além da descrição dos meios empregados para ocultar provas, de aulas de tortura com cobaias humanas e ainda 27 centros de tortura ${ }^{40}$.

A lista segue o cuidado das anteriores e demonstra o esforço empenhado

\footnotetext{
39 "Anistia. Proposta do MDB foi mesmo rejeitada". O Estado de S. Paulo, 19 de abril de 1979.

${ }^{40}$ Cf. Em Tempo, n.64, 18 a 24 de maio de 1979, capa.
} 
para garantir confiabilidade ao levantamento, realizado a partir da experiência direta dos presos ou do testemunho do tratamento sofrido pelos que estiveram detidos com eles. Os autores destacaram, mais uma vez, a incopletude da lista e a necessidade de ampliar a investigação sobre o aparato repressivo e os torturadores (IDEM).

Em 8 de julho de 1979, a sucursal de Belo Horizonte de Em Tempo sofreu novo ataque, cuja autoria não foi reivindicada. Nesse período, o semanário publicou diversas matérias que colocavam em cheque o regime, assim como aqueles diretamente ligados ao que se costumava denominar "trabalho sujo". Os editores do jornal demonstraram cautela diante da condenação pública do atentado feita pelo general-presidente João Batista Figueiredo: "A 'mão estendida' e o 'braço clandestino' fazem parte do mesmo corpo" ${ }^{41}$; ressaltando as ambiguidades e fragilidades do processo de distensão política.

A coragem dos editores de Em Tempo pela publicação das listas de torturadores foi reconhecida com o Prêmio Vladimir Herzog, em outubro de 1979. Não obstante os esforços dos militares para dissuadir a militância, este cenário impulsionou a campanha pela anistia ampla, geral e irrestrita no ano de 1979. A efervescência da sociedade civil crescia, enquanto os militares buscavam retomar o controle do processo de abertura política.

\section{A defesa de todos os atingidos e da memória da repressão}

O movimento da anistia caracterizou-se pela profusão de posições; dir-seia que, no que se refere à escolha do projeto de lei a se defender, este se desenvolveu tanto por distinções quanto por concordâncias. Uma visão deste cenário pode ser apreciada em relação aos ocorridos em torno do 3o. Encontro Nacional dos Movimentos de Anistia, que teve lugar no Rio de Janeiro, de 15 a 17 de junho de 1979.

Este encontro propiciou condições para que duas faces da anistia entrassem em confronto: uma voltada à popularização da luta e sua vinculação com as organizações e lutas populares e outra voltada à defesa dos atingidos pela repressão política e à busca de apoio internacional. Esta discussão entremeouse com o debate em torno do projeto de anistia parcial do governo, que tomou grande parte do Encontro (GRECO, 2003, p.131).

${ }^{41}$ Cf. Em Tempo, 12 a 18 de julho de 1979, capa. 
A expansão dos espaços públicos tomados pela luta pela anistia fazia-se evidente e o parlamento possuía um papel fundamental em tal desenvolvimento. No entanto, seu papel permaneceu problemático e contraditório, devido aos contatos insuficientes com a oposição e à fragilidade das relações com os parlamentares. Os compromissos assumidos pelo MDB mostraram-se mais formais do que reais - em muitos casos por força do caráter "extraordinariamente moderado" da agremiação (SKIDMORE, 1990, p.70).

Havia o consenso de que o projeto (de anistia parcial) do governo era insatisfatório, posto que não contemplava os militantes que haviam participado da luta armada. Uma parte das esquerdas acreditava na necessidade de medidas de impacto para mobilizar setores do congresso e da sociedade civil em relação à anistia ampla e irrestrita. Dentro deste segmento, os presos políticos do Rio de Janeiro possuíam uma posição mais radicalizada, em face da qual organizaram a greve de fome nacional pela anistia geral, que transcorreu entre julho e agosto de $1979^{42}$. A greve representou um momento decisivo na ocupação dos espaços públicos e serviu, não apenas para forçar os limites da proposta de lei de anistia, aumentando o leque de beneficiários da anistia, mas para denunciar os crimes da repressão.

Os presos de São Paulo opuseram-se a esta visão, solicitando que a greve de fome fosse postergada para uma data próxima à da votação da lei no Congresso Nacional, o que não foi seguido pelo grupo carioca, o qual buscava catalisar os movimentos em defesa da anistia e da opinião pública. Assim é que a greve teve início, em 22 de julho, inicialmente envolvendo 14 detentos do presídio da Frei Caneca (Rio de Janeiro) e se ampliando até o envolvimento de 35 presos (dos 53 existentes) de seis estados brasileiros (GRECO, 2003, p.212-3; n.391). Conforme relatou-nos Manoel Cyrillo, preso no Romão Gomes nesse período:

"A gente tinha uma posição que era a de que não podíamos interferir tanto no movimento social, provavelmente, porque, em São Paulo, [...] o movimento estava muito mais ativo, na rua, diferentemente do Rio, onde a participação deles foi decisiva para a coisa tomar mais corpo. Não era um problema interferir, mas passar por cima dos movimentos.

[...] Nós éramos contra a greve e por isso não entramos simultaneamente, mas [...] a gente entrou, mesmo com a denúncia

${ }^{42}$ Cf. LINS (2008); e VIANA (2011). 
dos cinco presos que não quiseram entrar $[\ldots]$.

O que eu acho é que eles atribuíram uma importância muito superior ao papel dos presos do que nós achávamos que era o correto. Isso pode até ser considerado como um vanguardismo da parte deles (CYRILLO, 2011)”.

Enquanto transcorria a greve, manifestações públicas de apoio à anistia ampla e irrestrita expandiam-se. Um ato público organizado no dia 14 de agosto, no Rio de Janeiro, contou com a presença de 20 mil pessoas. Outro ato organizado na Praça da Sé no dia 21 de agosto teve a participação de cerca de 30 mil manifestantes (CIPRIANO, 1992, p.136-7; 168-9). Diversas pessoas, personalidades e representantes de entidades foram aos presídios visitar os grevistas, atuando como formadores de opinião.

Este clima perdurou até a votação da Lei da Anistia, em 22 de agosto de 1979. Entre muitas discussões, o movimento decidiu apoiar a proposta de emenda Djalma Marinho, que não havia sido aceita pelos CBAs de Minas Gerais e de São Paulo, em função da equiparação que promovia entre repressores e vítimas. O resultado da votação surpreendeu; a proposta de conceder destaque (isto é, preferência) ao substitutivo do MDB foi derrotada por 209 votos contra 194, com o apoio de 12 arenistas dissidentes. Após obter o destaque, a emenda Djalma Marinho por pouco não foi vitoriosa, recebendo 201 votos a favor e 206 contra. Ao fim, o projeto de anistia do governo foi aprovado pela votação dos líderes dos dois partidos, não sendo possível a votação nominal. Não obstante, 29 dos 189 deputados do MDB apresentaram sua declaração de voto contrário ao projeto, denunciando a falta de isonomia na concessão da anistia, recusando-se a legitimar a nova lei.

A "votação" do projeto de Lei de Anistia dos militares pôs fim à greve de fome, a qual foi considerada vitoriosa pelos presos (a despeito de seus efeitos práticos parciais), conforme permitiu a divulgação de denúncias e propostas, bem como a sedimentação de seu estatuto de "prisioneiros de consciência” perante a opinião pública. Este movimento foi sucedido pela reforma partidária de outubro de 1979, a qual envolveu divergências em graus diversos entre a opção de se priorizar a organização de novos partidos políticos e o fortalecimento dos sindicatos, e a manutenção dos movimentos de anistia por reparações simbólicas, materiais e justiça. Esta segunda opção acabou mitigada pela força da primeira, a despeito do fato de as atividades reivindicatórias terem caminhado no sentido da organização de campanhas, i.e., libertação dos últimos presos políticos (Flávia Schilling, Flávio Koutzii, 
José Salles), retorno de exilados e estrangeiros expulsos do Brasil e extinção da Lei de Segurança Nacional.

O trauma causado pelo isolamento social ao qual as esquerdas revolucionárias foram relegadas, a ansiedade pela retomada da vida pessoal e o afã de se estabelecer novas organizações políticas deixou inconcluso o processo de autocrítica iniciado por remanescentes dos grupos aniquilados pela ditadura (TELES, 2011). Assim é que essas bandeiras políticas gradualmente tiveram seus escopos restritos à militância de familiares de mortos e desaparecidos e de alguns sobreviventes. Desse modo, os pequenos grupos formados em torno dessa temática não conseguiram mobilizar a opinião no sentido de extinguir a LSN (reformada em 1983 e em vigor na atualidade) ou estabelecer uma lei contra a tortura na Constituinte de 19871988.

Conforme a interpretação predominante da lei da anistia vedava a investigação dos crimes da ditadura (TELES, 2005), a derradeira apuração dos fatos permaneceu obliterada, impossibilitando o conhecimento público dos fatos. Respondendo a esta conjuntura, um pequeno grupo de advogados, militantes e ex-presos políticos deitou as bases do projeto Brasil: Nunca Mais (BNM), produzido entre 1979 e 1985, por meio da compilação dos dados dos arquivos da justiça militar de 1964 a 1979. Um livro homônimo com os principais resultados da pesquisa foi publicado em julho de 1985. O BNM chegou a uma nova lista de torturadores, contendo 444 nomes, a qual foi divulgada na imprensa em dia 21 de novembro, poucos dias depois das primeiras eleições municipais realizadas sob um regime civil (WESCHLER, 1990, p.75, 82). A opção por manter a lista inédita até a sua divulgação à imprensa, ao invés incluí-la no livro refletiu a avaliação da equipe de pesquisadores envolvidos no projeto de que seria oportuno esperar o arrefecimento da tensão política neste momento de "frágil" transição.

Esta lista era uma continuidade dos levantamentos elaborados pelos presos políticos, publicados em livros e pelo jornal Em Tempo. No BNM, no entanto, os nomes apresentados eram resultado do levantamento dos nomes citados na justiça militar, contendo a identidade de quem os denunciou em juízo e o número do processo correspondente ${ }^{43}$. É digno de nota que a

\footnotetext{
${ }^{43}$ Em 2010, grupos de defesa dos direitos humanos divulgaram uma lista de nomes de 1.600 torturadores do período ditatorial, chamada Torturadores de A a Z. Cf. http://biakushnir. wordpress.com/2010/01/12/pequena-lista-para-ser-lembrada-neste-momento.
} 
análise comparativa da lista de torturadores produzida em 1975 e daquela divulgada pelo BNM apresenta uma característica comum: a notória presença de militares oficiais envolvidos diretamente na tortura ${ }^{44}$. Ademais, alguns dos presos que ajudaram a organizar estas listas nos cárceres ao longo da década de 1970 participaram ativamente do projeto BNM, tais como Paulo Vannucchi, Carlos Lichtsztejn e Rene de Carvalho (TELES, 2011).

O BNM pautou-se pela estratégia de fazer uso exclusivo de fontes documentais, oriundas da justiça militar do próprio regime, o que representou um fator decisivo para que se garantissem confiabilidade e legitimidade à obra. Por outro lado, o caráter oficial da documentação e, principalmente, sua origem nos tribunais de exceção trouxe limitações e peculiaridades às informações compiladas, tal como a ausência de alguns dos nomes de torturadores, citados no documento dos presos do Rio de Janeiro (1979), na lista publicada. Estas ausências relacionam-se ao fato destes terem sido torturados após a condenação pela justiça militar, conforme o caso mencionado ocorrido na Fortaleza de Santa Cruz.

A despeito destas características, o papel do BNM na divulgação dos crimes da ditadura é paradigmático; o projeto influenciou - e ainda tem influenciado - todas as iniciativas de resgate da história da ditadura que sucederam, informando pesquisadores e sustentando investigações.

\section{Considerações finais}

Neste artigo procuramos revelar aspectos pouco conhecidos da atuação dos presos políticos (em especial os de São Paulo) nas lutas de resistência à ditadura no Brasil durante os anos 1970, por meio de sua atuação na sistematização e divulgação de denúncias de violações dos direitos humanos, em especial, das listas de torturadores.

Tais considerações apontam para uma atuação mediada por estratégias diversas, tais como protestos e greves de fome para obter melhores condições

\footnotetext{
${ }^{44}$ EDe acordo com duas pesquisadoras que analisaram estas listas: no universo de 1.010 nomes, $650(64,3 \%)$ são passíveis de localização, ao passo que $360(35,7 \%)$ não são identificáveis. A presença dos militares prepondera na relação com os civis, a qual oscilou entre $41 \%$ a $64 \%$. O Exército é a força de origem dos agentes do Estado mais presente entre os acusados de praticar torturas, variando entre $65 \%$ e $69 \%$ do total. A presença de oficiais também foi marcante, a qual various entre $54 \%$ e $63 \%$. Cf. CHIRIO e JOFFILY (2014), p.92-95.
} 
carcerárias e o reconhecimento de sua condição de "prisioneiros de consciência”. Por vezes, esses caminhos mostravam-se incapazes de superar os determinantes impostos pelo regime de exceção, ao mesmo tempo em que contribuíam positivamente para a conquista de melhorias no tratamento dispensado aos presos, a geração de pressões políticas e a construção de uma contramemória sobre os crimes da ditadura. Estas ações inserem-se no contexto mais amplo das pressões exercidas pelas redes de solidariedades e apontam para vínculos importantes com as vozes atuantes no exterior que se mostraram fundamentais para dar visibilidade ao que acontecia no país e para o fim da ditadura.

Pautado pelo registro das memórias dos presos políticos, este estudo permitiu-nos traçar um quadro a respeito de sua organização, da sistematização das denúncias de tortura e das listas de torturadores, assim como aprofundar nosso conhecimento sobre as disputas políticas estabelecidas dentro e fora dos cárceres, especialmente, no período das lutas pela anistia ampla, geral e irrestrita.

A interpretação predominante da lei da anistia (considerada recíproca) vedou a investigação dos crimes da ditadura e a derradeira apuração dos fatos permaneceu obliterada, impossibilitando o conhecimento público dos fatos. Dir-se-ia que o Brasil avançou a partir das experiências aqui relatadas, mas ao mesmo tempo não soube aproveitar a oportunidade para gerar processos de responsabilização que efetivamente refletissem a real magnitude dos eventos consumados naquele período.

\section{Referências}

ALVES, Márcio Moreira. (1967). Torturas e torturados. 2a. ed., Rio de Janeiro, Idade Nova.

BENEDITO, Mouzar e REZENDE, José Roberto. (2000). Ousar lutar. Memórias da guerrilha que vivi. São Paulo, Viramundo.

BENEVIDES, Maria Victória de Mesquita. (2009). Fé na Luta. A Comissão Justiça e Paz de São Paulo, da ditadura à democratização. São Paulo, Lettera.

BIOCCA, Ettore. (1974). Estratégia do Terror. A face oculta e repressiva do Brasil. Lisboa/Portugal, Iniciativas Editoriais.

CIPRIANO, Perly; VIANA, Gilney Amorim.

(1992). Fome de Liberdade. A luta dos presos políticos pela anistia. Vitória, s.n.

CHIRI0, Maud; JOFFILY, Mariana.

(mai. de 2014). “La répression en chair et en os: les listes d'agents de l'État accusés d'actes de torture sous la dictature militaire brésilienne". In: Maud Chirio; Mariana Joffily (Orgs.); Brésil(s). Sciences humaines et soliales, p.77-103. 
DA-RIN, Silvio.

(2006). Hércules 56. Brasil, documentário, 92 $\min$.

(2008). Hércules 56. 0 sequestro do embaixador americano em 1969. Rio de Janeiro, Zahar,

DIAS, Luzimar Nogueira (org.).

(1979). Esquerda armada. Testemunho dos presos políticos do presídio Milton Dias Moreira, no Rio de Janeiro. Vitória, Ed. do Leitor.

FERNANDES JR., Ottoni.

(2004). 0 baú do guerrilheiro. Memórias da luta armada urbana rural. Rio de Janeiro, Record.

FIC0, Carlos.

(2001). Como eles agiam. Os subterrâneos da ditadura militar: espionagem e polícia política. Rio de Janeiro, Record.

(2004). Além do golpe: versões e controvérsias sobre 1964 e a ditadura militar. Rio de Janeiro, Record.

JOSÉ, Emiliano.

(2000). As asas invisiveis do Padre Renzo. São Paulo, Casa Amarela.

KUCINSKI, Bernardo.

(2001). 0 fim da ditadura militar. São Paulo, Contexto.

(2003). Jornalistas e revolucionários: nos tempos da imprensa alternativa. São Paulo, Edusp.

GRECO, Heloísa Amélia.

(2003). Dimensões fundamentais da luta pela anistia. Tese apresenta ao Programa de Pósgraduação em História da Universidade Federal de Minas Gerais (UFMG). Belo Horizonte.

GREEN, James Naylor. Apesar de Vocês.

(2009). Apesar de Vocês. Oposição à ditadura brasileira nos Estados Unidos (1964-1985). São Paulo, Companhia das Letras.

GASPARI, Elio.

(2002). A Ditadura Escancarada. São Paulo, Companhia das Letras.
MEL0, Alice; LIMA, Vivi Fernandes de.

(29 de dezembro de 2011). “A lista dos acusados de tortura". Revista História. Rio de Janeiro.

NAPOLITANO, Marcos.

(2005). Cultura e poder no Brasil contemporâneo. Curitiba, Juruá.

PAIVA, Maurício.

(2004). 0 sonho exilado. 2a . ed., Rio de Janeiro, Mauad.

SÁ, Ayberê Ferreira de.

(2007). Das ligas camponesas à anistia. Memórias de um militante trotskista. Recife, Fundação de Cultura Cidade de Recife.

SKIDMORE, Thomas.

(1990). "A lenta via brasileira para a democratização". In: Thomas Skidmore; Alfred Stepan (Orgs.). Democratizando o Brasil. Rio de Janeiro, Paz e Terra.

TELES, Janaína de Almeida.

(2005). Os herdeiros da memória: a luta dos familiares de mortos e desaparecidos políticos por "verdade e justiça" no Brasil. Dissertação de Mestrado apresentada ao Programa de Pósgraduação em História da Universidade de São Paulo (USP). São Paulo.

(2011). Memórias dos cárceres da ditadura: os testemunhos e as lutas dos presos políticos no Brasil. Tese de Doutorado apresentada ao Programa de Pós-graduação em em História da Universidade de São Paulo (USP). São Paulo.

TELES, Janaína de Almeida, RIDENTI, Marcelo; IOKOI, Zilda Márcia Gricoli. (orgs.).

(2010). Intolerância e Resistência: Testemunhos da repressão política no Brasil (1964-1985). São Paulo, FFLCH/USP, 2010.

WESCHLER, Lawrence.

(1990). Um milagre, um universo: o acerto de contas com os torturadores. São Paulo, Companhia das Letras. 


\section{Documentos consultados}

ANISTIA INTERNACIONAL.

(1972). "Relatório sobre as acusações de torturas no Brasil". ASMOB 03.15, 2, Arquivo do CEDEM/UNESP.

ALMEIDA, Criméia: LISBÔA, Suzana; TELES, Janaína de Almeida; TELES, Maria Amélia. (Orgs.).

(2009). Dossiê Ditadura: mortos e desaparecidos políticos no Brasil (1964-1985). São Paulo: IEVE/Imprensa Oficial.

ARQUIDIOCESE DE SÃO PAULO.

(1989). Brasil: Nunca Mais. 22a . ed., Rio de Janeiro, Vozes.

COMITÊ PRÓ-AMINISTIA GERAL DOS PRESOS POLIITICOS NO BRASIL.

(1976). “Apresentação". In: Dos presos políticos brasileiros. Acerca da repressão fascista no Brasil. Lisboa, Ed. Maria da Fonte, 1976.

MORANO FILHO, Reinaldo.

(05 de Junho de 2002). "Atestado de Permanência e Conduta" (Casa de Detenção). In: Requerimento de Reinaldo Morano Filho dirigido à Comissão Especial da Secretaria da Justiça e da Defesa da Cidadania do Estado de São Paulo. São Paulo/SP, Arquivo pessoal de Reinaldo Morano Filho.

\section{Entrevistas citadas}

ALBUQUERQUE, Rômulo Noronha de.

(22 de março, 2010). Entrevista concedida a Janaina de A. Teles. Rio de Janeiro (RJ). Arquivo Audiovisual sobre Presos Políticos (AAPP)/Arquivo Edgard Leuenroth-Diversitas (USP).

AZEVEDO, Ricardo de.

(27 de janeiro, 2010). São Paulo/SP. Entrevista concedida a Janaína de Almeida Teles. AAPP/ AEL-Diversitas (USP).

BENEDITO, Mouzar e REZENDE, José Roberto. (2000). Ousar lutar. Memórias da guerrilha que vivi. São Paulo, Viramundo.
BRAMBILLA, Celso Giovanetti.

(18 de dezembro, 2009). São Paulo/ SP. Entrevista concedida a Janaína de AlmeidaTeles. AAPP/AEL-Diversitas (USP).

CUNHA, Carlos Alberto Lobão.

(05 de maio e 17 de setembro, 2009). São Paulo/SP. Entrevista concedida a Janaína de Almeida Teles. AAPP/AEL-Diversitas (USP).

(10 de outubro, 2010). São Paulo/SP. Entrevista concedida a Janaína de Almeida Teles.

DEL ROI0, José Luiz.

(29 de março, 2010). São Paulo/SP. Entrevista concedida a Janaína de Almeida Teles.

KUCINSKI, Bernardo.

(05 de outubro, 2012). São Paulo/SP. Entrevista concedida a Janaína de Almeida Teles.

MARTINS, Roberto Ribeiro.

(01 de abril, 2009). São Paulo/SP. Entrevista concedida a Janaína de Almeida Teles. AAPP/ AEL-Diversitas (USP).

MELO, Marcelo Mário de.

(27 de novembro, 2009; 23 de abril, 2010). Entrevista concedida a Janaína de Almeida Teles. Recife (PE). AAPP/AEL-Diversitas (USP).

MORANO FILHO, Reinaldo.

(14 de março, 2011). São Paulo/SP. Entrevista concedida a Janaína de Almeida Teles.

(17 de outubro, 2008; 16 de abril, 2009) Entrevista concedida a Janaína de Almeida Teles. AAPP/AEL-Diversitas (USP). São Paulo/ SP.

MURAT, Lúcia.

(25 de março, 2010). Rio de Janeiro/RJ. Entrevista concedida a Janaína de Almeida Teles. In: Janaína de Almeida Teles; Marcelo Ridenti; Zilda Márcia Grícoli Iokoi (Orgs.); Intolerância e Resistência: Testemunhos da repressão política no Brasil (1964-1985). São Paulo, FFLCH/USP. p.353-398. 
NETTO, Manoel Cyrillo de Oliveira.

(08 e 30 de novembro, 2009; 27 de janeiro, 2010). São Paulo/SP. Entrevista concedida a Janaína de Almeida Teles. AAPP/AELDiversitas (USP).

(20 de março, 2011). São Paulo/SP. Entrevista concedida a Janaína de Almeida Teles.

PAES, Márcia Basseto.

(18 de junho e 28 de setembro, 2009). São Paulo/SP. Entrevista concedida a Janaína de Almeida Teles. AAPP/AEL-Diversitas (USP).

ROCHA FILH0, Pedro.

(05 de março, 2010). São Paulo/SP. Entrevista concedida a Janaína de Almeida Teles. AAPP/ AEL-Diversitas (USP).

SOARES, Carlos Alberto.

(23 de abril, 2010). Recife/PE. Entrevista concedida a Janaína de Almeida Teles. AAPP/ AEL-Diversitas (USP).
LINS, Paulo Henrique.

(23 de novembro, 2008). Rio de Janeiro/RJ.

Entrevista concedida a Janaína de Almeida

Teles. AAPP/AEL-Diversitas (USP).

TELES, Maria Amélia de Almeida.

(05 de março, 2013). São Paulo/SP. Entrevista concedida a Janaína de Almeida Teles.

VIANA, Gilney Amorim.

(05 de março, 2011). São Paulo/SP. Entrevista concedida a Janaína de Almeida Teles.

\section{Jornais}

(8 a 14 março de 1979). “Saiu o 2. Listão: 442 torturadores". Em Tempo, no. 54.

\section{Recebido em}

abril de 2014

Aprovado em

agosto de 2014 